(https://creativecommons.org/licenses/by-nc/4.o/)

\title{
Assessment of Applying Saudi Labour Law to Digital Platform Workers: Taking Uber as an Example
}

\author{
Meshal Nayef Alharbi \\ Department of Law, \\ College of Science and Theoretical Studies, \\ Saudi Electronic University, Riyadh, Saudi Arabia
}

DOI: https://doi.org/10.36941/ajis-2021-0116

\section{Abstract}

The use of technology platforms has become quite common and popular worldwide. Some of these platforms have used for business purpose such as connecting taxi drivers with riders or providing delivery services. At present, there are famous institutions employing persons to provide their services through digital platforms, and in some states, such persons are considered workers. In the Kingdom of Saudi Arabia, it is significant to find a direct answer to whether or not persons using digital labour platforms to offer services could be regarded as workers, and the Saudi Labour Law must, or not, be applied to govern their contracts with the enterprises that own these platforms. This paper aims to find a legal solution to this issue and concentrates on digital platform workers in Saudi Arabia. It examines mainly legal sources relating to Saudi Labour Law such as books, and investigates a number of reported judgments issued by the Commission for the Settlement of Labour Disputes in Saudi Arabia in 2010 and 2011.It also reviews relative information provided on the web sites of Uber. The finding is that the traditional rules of Saudi Labour Law should apply to these types of work agreements, and persons rendering their services through digital platforms must be protected by the rules established in the Law, but, according to the recent provisions adopted by the Saudi Ministry of Human Resources and Social Development, it seems that they are considered as freelancers.

Keywords: Saudi Labour Law, smartphone apps, workers' rights, digital platforms workers

\section{Introduction}

In recent times, technology platforms are vital to our daily lives, not only for the public or students, but also for companies using these platforms to communicate with customers and to enhance their trade. In the first decade of the twenty-first century, trade enterprises have been established that rely mainly on digital platforms, such as taxi or food delivery services, and they are providing employment to many people. This transformation in the work set-up functioning by means of technology platforms has become popular to a great extent for various reasons, and nowadays, a lot of companies around the world are employing this business model. For instance, Uber is a famous enterprise that was founded in 2009. It was initially known as UberCab but renamed Uber in 2011. With headquarters in San Francisco (Chernev, 2017), Uber is a technology platform to provide taxi services by connecting drivers and riders (Uber, n.da). This institution is regarded by various big companies, and it was reported that in 2016, Uber served approximately 2 billion riders and saw a surge of more than 12 
billion dollars in capital, reaching 'an implied valuation of 66 billion \$, making it the highest valued startup in the world'(Chernev, 2017). On the other hand, working in this manner through digital platforms leads to several issues in the legal field. One of the controversial subjects is the nature of the work relationship between people who work through digital platforms and the owners of these platforms. In this regard, an important and logical question is 'Could these persons be considered workers in accordance with labour laws?'.

It is important to thoroughly investigate the nature of this work relationship and adopt an appropriate legal approach for persons employed by this business model in the Kingdom of Saudi Arabia. This is because according to statistics revealed on 10 November 2018, there were more than 485,00o Saudi drivers using their own cars and rendering their services through technology platforms in 6o Saudi cities to serve passengers, and their profits were approximately 2 billion Saudi Riyal a year (Ghawi, 2018). The people working on digital labour platforms in Saudi Arabia could be in a partnership agreement, self-employed contractors or workers according to Saudi Labour Law. In this context, if a contract is brought before a court, the trial judge must review and examine every clause of the agreement and give it the right legal characterization. For example, in cases where parties sign a partnership agreement, the judge might apply the rules of the labour law if he or she concludes that the right legal description for this contract is the employment agreement (Zaki, 1982; Aldumky, 2012; AlAhmed, 2015). Furthermore, it is important to clarify the nature of the work relationship between the employer and the worker, whether it is an employment agreement or other type of contract, in order to define which law shall be called to govern the agreement. Actually, the rules regulating the employment contract are different from those governing other agreements in terms of the concessions granted to workers, conditions for performing the work, risk of loss and responsibility (Abdualredha, 1984). Also, the significance of giving the right legal characterization to such an agreement between parties is highlighted when the employer does not interpret the relationship with the worker as an employment agreement in order not to apply the provisions of the labour law that grant many benefits to the worker (Abdualredha, 1984; Musa, 2018). In this sense, the prospective outcomes of this study are crucial for both persons and companies that employ them via digital platforms in order to clarify which law shall govern their work relationship.

In spite of the importance of this subject, there has not yet been found any reported judgement from Saudi courts presenting a direct approach for the Saudi Labour Law relating to the issue. Moreover, so far, it has not found any academic book or article that specifically addresses this topic although there are many of them describing and analysing the rules enacted in the Saudi Labour Law. At the same time, Article 7 of the Saudi Labour Law, which defines certain workers who are not subject to the application of the Law, cannot be relied on to find a remedy to this dilemma. This is because this Article does not exclude workers rendering their services through digital platforms from the application of the Saudi Labour Law. It states that ' $[\mathrm{t}]$ he following shall be exempted from the implementation of the provisions of this Law: A. The employer's family members, namely, the spouse, the ascendants and descendants who constitute the only workers of the firm. B. Players and coaches of sport clubs and federations. C. Domestic helpers and the like. D. Agricultural workers, special sheepherders, and the Like. E. Maritime workers working on board of vessels with a load of less than five hundred tons. F. Non-Saudi workers entering the Kingdom to perform a specific task for a period not exceeding two months'. Hence, there is a pressing need to reveal the legal nature of the work relationship in this type of work arrangement in Saudi Arabia.

\section{Research Methods}

This study aims to find an appropriate legal approach to be integrated into Saudi laws relating to digital platform workers, in particular, whether or not they are workers under the Saudi Labour Law. It relies on legal materials such as academic books and reviews a number of court's judgments that have been issued by the Commission for the Settlement of Labour Disputes in Saudi Arabia in 2010 and 2011.It also investigates online information which have provided on Uber's websites. To draw 
appropriate conclusions, several points have been discussed: First, some vital rules legislated in the Saudi laws linked to this issue have been mentioned. Second, the point of when the persons shall be regarded as workers in accordance with the Saudi Labour Law have been examined and revealed. Third, it is answered, in detail, to the question whether or not the work agreement between persons and enterprises employed them via digital platforms in Saudi Arabia must be governed by the Saudi Labour Law. Finally, this paper concludes with remarkable findings, and recommendations for future studies have been provided.

\section{Findings, Analysis and Discussion}

\subsection{General Rules Relating to Digital Platform Workers in Saudi Arabia}

When the subject 'application of the Saudi Labour Law to digital platform workers' is explored, there are various established principles in Saudi laws that must be taken into account. According to Section 1 of Article 25 of the Regulation for Taxi, Taxi Broker and Taxi Delivery Apps, taxi service providers offering services by means of digital platforms are prohibited from hiring non-Saudi drivers. Pursuant to the Regulation, the service providers must take into consideration the laws issued by relevant authorities. Also, they are obliged to implement an oversight mechanism for drivers. The taxi-service providers may be liable to financial fines if they do not follow the rules of the Regulation.

With respect to the Saudi laws promulgated by relevant Saudi authorities, it is significant to mention that it seems that taxi service providers working by means of digital platforms in Saudi Arabia do not mind their drivers to work on behalf of their competitors or other employers. However, according to the Implementing Regulation of Human Resources for government officials and the Law of Non-commissioned Officer Service, public servants and military officers are not authorized, in general terms, to work for another employer or run a business for themselves. Sections 5 and 7 of article 209 of the Implementing Regulation of Human Resources for government officials provides the principle that public servants are not allowed to work in trade or exercise other professions without permission. Regarding military personnel, section 3 of article 60 of the Law of Noncommissioned Officer Service provides that non-commissioned officers are not permitted to work in trade or be self-employed, with or without wage, and in case the non-commissioned officers are in breach of this rule, they might face military prosecution. As to the Saudi Labour Law, although it has been established that, in general terms, labour laws do not prevent a worker from signing more than one employment contract, and he or she could be in a work agreement with more than one employer (Zaki, 1982; Abdualredha, 1984), the Saudi Labour Law, in fact, provides a different view. Section 1 of article 39 of the Saudi Labour Law prevents a non-Saudi worker form working on behalf of another employer and states that 'unless he has followed the stipulated legal rules and procedures, an employer may not allow his worker to work for others, and a worker may not work for other employers. Similarly, an employer may not employ workers of other employers'. Also, section 2 of the Article enacts the principle that 'an employer may not allow a worker to work for his own account and a worker may not work for his own account'. The Saudi Labour Law does not regulate this subject in respect of Saudi workers in the private sector. Therefore, the parties to an employment agreement may include a clause regulating this matter, and in such situations, employers have the full right to prohibit Saudi workers from working on behalf of other employers. Hence, the general rule in Saudi laws is that public servants, non-Saudi workers in the private sector and military officers are forbidden to work for their own account or for other employers.

Furthermore, while investigating the legal nature of the work relationship between persons and enterprises offering services through digital platforms, it is pertinent to clarify how an employment contract is classified according to the rules of Sharia because these rules govern all regulations in Saudi Arabia and the applicable law in the country must not conflict with these principles at all. This fact is affirmed in Article 1 of the Law of Procedure before Shariah Courts, Article 1 of the Law of Procedures before the Board of Grievances and Article 48 of the Basic Law of Governance. All of these 
articles emphasize the doctrine that 'governance in the Kingdom of Saudi Arabia derives its authority from the Book of God Most High and the Sunnah of his Messenger, both of which govern this Law and all the laws of the State.', as stated in Article 7 of the Basic Law of Governance. Moreover, Article 46 of the Law institutes the same principle and upholds that ' $[t]$ he Judiciary shall be an independent authority. There shall be no power over judges in their judicial function other than the power of the Islamic Shari'ah'. In Islamic rules, the provisions of work contracts are usually investigated applying the principles of a leasing agreement, and in this regard, the accurate term 'a leasing agreement on work' or 'use of a person' should be used to describe a work agreement in Islamic jurisprudence (Alawawdah, 2010). In addition, in general terms, a leasing agreement on work is divided into two categories in Sharia: The first is private workers, and it exists, according to articles 422 and 425 of Majallah el-Ahkam-i-Adliya, when workers allocate their duties to one employer. In this classification, workers are entitled to the entire wage for the period agreed with the employer as long as they express their preparedness to perform their duties, even if they do not actually exercise their work. The second is common or public workers, and it applies, pursuant to articles 422 and 424 of Majallah el-Ahkam-i-Adliya, when workers perform or offer their services on behalf of the public, such as tailors, physicians and joiners. These types of workers shall be given their wage when they complete and hand over the work to which they agreed. Also, according to the rules of Sharia, the general principle is that a lease contract is consistent with Islamic rules as long as the agreement is for a specific task, the fare are recognized for the parties involved and the subject matter of the lease is allowed in Islamic rules (Alothaimeen, 2005). Hence, an employment agreement is classified as a leasing agreement in the rules of Sharia.

\subsection{The Work Agreement Governed by the Saudi Labour Law}

When it comes to the question 'Which work relationship shall be governed by the labour law', it can be said that it shall be called to govern an employment relationship if certain elements are available in the agreement, including the wage, work and employer's control (Allamsawi, 2007; AlAhmed, 2015; Hadfy, 2015). These elements mean that workers must perform their work for a certain wage, and in case they do an unpaid work or do not perform a work and have been given a certain amount of money, even if it is called a wage, the labour law should not govern these cases (Zaki, 1982; Bani Khalaf, 2018). The employer's control means that the workers do their work under the supervision and management of their employers, who have the right to penalize them in case they fail to follow the employers' instructions (Hadfy, 2015). The Saudi Labour Law is based on the same concept, and Section 1 of Article 5 of the Saudi Labour Law provides a direct and clear answer to when the Law should be called and applied. It, obviously, states that the Saudi Labour Law shall be applied to govern any contract whereby a person commits him or herself to work for an employer and under the management or supervision of the employer for a wage. Also, Article 2 of the Law defines the worker as Any natural person, male or female, working for an employer and under his or her management and supervision for a wage, even if he or she is not under the employer's direct control. In practice, the Commission for the Settlement of Labour Disputes confirms this principle in various reported judgements. For instance, the Superior Commission for the Settlement of Labour Disputes issued judgement no. 160/1/431 dated 19 January 2010, concluding that because the elements provided in Article 5 of the Law have not been fulfilled, it does not have the authority to rule on the issue and the Saudi Labour Law should not be applied to govern the case (The Code of the Labour Principles and Judgements, 2010, vol. 1, pp. 275-279). In addition, in judgement no. 344/2/432 issued on 21 February 2011, the Superior Commission for the Settlement of Labour Disputes affirmed the ruling of the Primary Commission for the Settlement of Labour Disputes in Mecca no. 278 dated 5 May 2010, concluding that it has the authority to rule on the litigation and the Saudi Labour Law shall govern the dispute because the worker performs his work under the supervision and management of the employer for a defined salary (The Code of the Labour Principles and Judgements, 2011, vol. 2, pp. 229-233). Hence, the Saudi Labour Law shall govern the employment agreement if the worker works 
under the employer's control for a certain wage.

In fact, the supervision and management of the employer is the most significant element in the employment agreement. It has been established that as long as the employer exercises control over the work of the worker, the rules of the labour law shall govern the work relationship. This is because there are various agreements to perform an agreed work for a defined wage, but the work agreement governed by the labour law must include the supervision and management of the employer (Abdualredha, 1984; Aldumky, 2012; Musa, 2018; Bani Khalaf, 2018). Then, the competent authority should apply the rules of the labour law to govern such an agreement if it concludes that there is actual administrative supervision and governance by the employer over the worker's performance of employment duties, even if the employer does not exercise technical supervision or control over the worker's work (Abdualredha, 1984). Not only this, this rule should also be followed even when the worker uses his or her own equipment to perform the work or has complete freedom to work at any time (Zaki, 1982). Furthermore, it suffices to apply the labour law to an agreement if the employer defines the location where the worker should work or the time when he or she must perform employment duties (Abdulrahman and Rushdy, 2009). More significantly, if a company leases a car to a driver who makes income driving it for a certain amount of money for the company, he or she will be regarded as a worker and the labour law should govern any potential disputes relating to this agreement, provided that the company oversees and directs the work of the driver (Abdualredha, 1984). Hence, the rule is that if the subject of an agreement is to do a defined work for a wage, the employer must supervise and control the worker's work in order to govern the agreement by the labour law.

In practice, the competent courts for labour disputes in Saudi Arabia have understood this concept. For example, it has been upheld in judgement no. 593/2/432 issued on 10 May 2011 that according to the definition of the worker provided in the Saudi Labour Law, the most significant element to govern a work relationship by the Saudi Labour Law is that the worker must work under the supervision and management of the employer (The Code of the Labour Principles and Judgements, 2011, vol. 1, pp. 149-157). Moreover, in judgement no. 2154/1/431 dated o5 December 2010, the Superior Commission for the Settlement of Labour Disputes concluded that because the employer did not direct or control the work of the worker, the Saudi Labour Law shall not be applied to the litigation (The Code of the Labour Principles and Judgements, 2010, vol. 1, pp. 339-343). In addition, when the supervision and management of the employer is absent in a work relationship, any prospective dispute would absolutely fall outside the jurisdiction of the Commission for the Settlement of Labour Disputes. The Superior Commission for the Settlement of Labour Disputes has confirmed this principle in judgements No. 1945/1/431 issued on o1 November 2010 (The Code of the Labour Principles and Judgements, 2010, vol. 1, pp. 57-66.) and No. 991/2/431 dated 29 September 2010 (The Code of the Labour Principles and Judgements, 2010, vol. 1, pp. 125-127). In addition, it is reported that a French court has ruled that taxi drivers are regarded as workers, and therefore, the labour law shall govern their agreement with employers as long as the employers direct and govern the duties performed by their drivers. The forum established that it is a pattern of direction if the employer obliges the driver to wear a specific dress or exhibit a defined behaviour with riders. The same rule is applied if the driver works under the official examination through the taxi company's inspectors or if the company is responsible for paying compensation or repairing the damage of the vehicle (Zaki, 1982). Certainly, the judgements issued by competent courts indicate that the supervision and management of the employer is a vital element required to govern any work agreement by the labour law.

\subsection{The Possibility of Considering Workers Providing Services Through Digital Platforms as Employees}

It is significant to have an international view of the issue of whether or not digital platform workers, such as Uber drivers, are regarded as employees pursuant to the rules of labour and employment 
laws. In the United Kingdom, On 10 November 2017, the Employment Appeal Tribunal confirmed the Employment Tribunal's decision and concluded, in the case of Uber B.V. and others v. Mr. Y. Aslam and others (2017) UKEAT/0056/17/DA, that Uber drivers are regarded as workers when they switch on the Uber app, and therefore, they would be 'engaged on working time for the purposes of regulation 2(1)' of the Working Time Regulations Act 1998. The rationales leading the tribunal to issue this decision were as follows: '(1) The contradiction in the Rider Terms between the fact that ULL purports to be the drivers' agent and its assertion of 'sole and absolute discretion' to accept or decline bookings. (2) The fact that Uber interviews and recruits drivers. (3) The fact that Uber controls the key information (in particular the passenger's surname, contact details and intended destination) and excludes the driver from it. (4) The fact that Uber requires drivers to accept trips and/or not to cancel trips, and enforces the requirement by logging off drivers who breach those requirements. (5) The fact that Uber sets the (default) route and the driver departs from it at his peril. (6) The fact that UBV fixes the fare and the driver cannot agree a higher sum with the passenger. (The supposed freedom to agree a lower fare is obviously nugatory.) (7) The fact that Uber imposes numerous conditions on drivers (such as the limited choice of acceptable vehicles), instructs drivers as to how to do their work and, in numerous ways, controls them in the performance of their duties. (8) The fact that Uber subjects drivers through the rating system to what amounts to a performance management/disciplinary procedure. (9) The fact that Uber determines issues about rebates, sometimes without even involving the driver whose remuneration is liable to be affected. (10) The guaranteed earnings scheme (albeit now discontinued). (11) The fact that Uber accepts the risk of loss which, if the drivers were genuinely in business on their own account, would fall upon them. (12) The fact that Uber handles complaints by passengers, including complaints about the driver. (13) The fact that Uber reserves the power to amend the drivers' terms unilaterally'. Hence, in the United Kingdom, Uber drivers are considered workers, as decided by the Employment Tribunal.

In contrast, in the United States, there is an opposite approach that has been presented by the Eastern District of Pennsylvania in the case of Razak v. Uber Techs., Inc., CIVIL ACTION NO. 16-573 (E.D. Pa. Apr. 11, 2018). In this litigation, the court concluded that in accordance with the Fair Labor Standards Act, drivers for UberBLACK are independent contractors because they 'have not brought to the record sufficient proof to meet their burden of showing that they are employees'. Also, in Australia, it has been decided, in the case of Mr Michail Kaseris v Rasier Pacific V.O.F (U2017/9452), that Uber drivers shall not be regarded as employees and one of the reasons is that they have a high degree of freedom to decide which hours they want to work and which trip requests they want to choose. Hence, in some countries, drivers using digital platforms to render their services, such as Uber drivers, are not considered employees.

\subsection{The Possibility of Regarding Digital Platform Workers as Workers in Accordance with Saudi Labour Law}

In this section, the nature of work relationship between companies providing their services via digital platforms and such drivers in Saudi Arabia will be examined in order to disclose whether or not they are workers, according to the Saudi Labour Law. It is important to mention that there has not yet been found any written agreement between enterprises providing taxi or delivery services via technology platforms and such drivers although this is vital to be examined in order to reveal the nature of the employment relationship. Instead, Uber's website would be explored to answer this question. It has been chosen to be examined because Uber is one of the oldest and largest enterprises using this business model in Saudi Arabia. It launched its services officially via digital platforms on 21 May 2014, and prior to this date, it was on a trial period for 3 months (Al Omran, 2014). However, the outcomes of this analysis are not restricted to Uber and its drivers, but any enterprise employed 
persons by digital platforms in Saudi Arabia, such as Careem ${ }^{1}$, would be regarded logically at the same legal position, as long as the required criteria are met.

Pursuant to the information provided on Uber's website, the nature of services is that a driver uses his or her own vehicle 'or a fleet partner's vehicle to pick up riders and drive them to preferred destinations' (Uber, n.da), and for each completed journey, the driver is entitled to be paid a fare as a certain percentage of the total amount paid by the rider (Uber, n.db). Pursuant to these facts, it is obvious that two of the elements stipulated to regard such a driver as a worker in accordance with the Saudi Labour Law are fulfilled, which are the work and wage, because Uber offers the work as a taxi driver and the wage is a defined percentage of the trip fare. In this context, it is important to mention that the Saudi Labour Law does not require the work contract to be for a specific period and it could be ratified for doing a particular duty, as Article 57 of the Law provides that if the contract involves performance of a specific work, it shall terminate with the completion of the work agreed upon'. At the same time, following Sections 1 and 2 of Article 96 of the Saudi Labour Law, the parties to the employment agreement are allowed to define the worker's entire wage on the basis of a percentage of the sale or productivity. In such a situation, giving wages to the workers on the basis of their productivity is the best method to encourage them to be more active and dynamic in spite of a lot of criticism against this method of salary payment (Zaki, 1982; Aldumky, 2012; AlAhmed, 2015; Musa, 2018). Hence, because Uber's drivers perform their work through the Uber app on behalf of the company for a specific percentage of the journey fare, two of the mandatory standards to apply the Saudi Labour Law to the work contract are available at this point.

As far as evaluating the degree of supervision and management of Uber on its drivers in Saudi Arabia is concerned, it is worth noting that every driver is obliged to work and pick up riders in certain selected areas or cities, which have to be agreed upon and confirmed by Uber, and the drivers are not allowed to provide taxi services in different cities. If they want to do so, they must examine driving stipulations for the new city or area in which they would like to drive, and there are certain steps that must be followed in such circumstances (Uber, n.dc). Also, the company is responsible for offering free insurance to 'all Uber riders, passengers, drivers and delivery partners' (Uber, 2018). The riders are insured from the moment of accepting the request for a trip through to when the journey terminates or is cancelled. Consequently, if an accident occurs during the trip, Uber, not the driver, is obliged to protect the rider against medical costs (Uber, 2018). This insurance cover includes the following: 'Medical cover: If an accident happens On-Trip, this cover reimburses' the rider 'for necessary medical costs' she or he has 'incurred following the accident (e.g. X-ray, operations, medicines) up to a capped sum. Death and repatriation payments: In the unfortunate event that' the rider dies 'as a result of an accident On-Trip,' his or her 'dependents or heirs will benefit from a lump sum payment. Repatriation expenses: In the unfortunate event that' the rider dies or is 'seriously injured (on the advice of competent medical authorities) as a result of an accident,' his or her 'dependents or heirs will benefit from a lump sum payment to cover reasonable repatriation expenses. Permanent disability payments: In the unfortunate event that' the rider suffers 'a permanent disability as a result of an accident On-Trip,' he or she 'will benefit from a lump sum payment, up to a capped sum. The amount depends on the severity of the disability, as determined by AXA' (Uber, 2018). Then, Uber has set general conditions that its drivers have to meet, and it offers free traffic accident insurance to its drivers and customers.

On the contrary, Uber controls the earnings of its drivers and assesses the procedures of how they should be paid. In this situation, Uber's drivers are allowed to receive the cost of a trip in cash, and it has been ruled that 'driver's app will confirm the total fare when the trip ends', and when the rider pays this amount to the driver in cash, the company emails him or her a receipt for the trip, but if a rider requests a cash trip, he or she will 'be unable to switch to another payment method' (Uber,

${ }^{1}$ It is a technology platform for taxi services. For more details, see https://www.careem.com/en-ae/our-story/ 
n.dd). Actually, Uber deducts a certain percentage of the fare for each trip, and the rest is the earning of the driver (Uber, n.db), which is transferred automatically to his or her bank account after two or three days of 'the end of the weekly cycle' (Uber, n.de). In addition, Uber itself determines the fare for the trip, and under certain circumstances, it has the full right to change or reduce the earnings of the driver without his or her consent. If a customer requires a fare review on the basis of the allegation that the driver did not take an ideal route or start or end the journey in time. The same rule applies if the 'driver refuses the rider's destination' (Uber, n.df). Another principle introduced by Uber for calculating a journey cost is that the waiting time during the journey is included in the total fare, and in case a rider asks the driver to stop during a journey, the fare for the trip shall be 'determined by the route's total time and distance'(Uber, n.dg). Furthermore, Uber has the full right to suspend the earnings from a selected trip for review in certain situations, such as when the cost of the journey is too high, and it may use a handy review for some fares for security reasons (Uber, n.dh). Consequently, Uber practices remarkable controls on ride fares.

Uber has also laid down rules to regulate trip cancellations, and its driver is entitled to obtain a certain amount of money if the rider cancels the trip after the driver has accepted it. This fee is regarded as compensation for the time and effort by the driver in getting to the rider location (Uber, n.di). Nonetheless, the driver may not receive any compensation in certain situations. If, for instance, he or she took much longer than expected in arriving at the rider location or if the company realises that the driver did not make much movement to the customer's pickup location (Uber, n.di). Moreover, it has been ruled that if the driver consistently declines 'consecutive trip or order requests in a row,' Uber 'technology may assume' that he or she does 'not want to confirm availability for more trips or orders or' has 'forgotten to log out, and' he or she 'may be temporarily logged out' (Uber, 2020). Moreover, it has been enacted that for every city, there is a minimum average star rating, and drivers' ratings should not below the limit assessed in the cities in which they drive. Uber drivers who 'don't meet the minimum average rating for their city may lose access to the Uber app'(Uber, 2020). In this way, Uber has established strict and binding rules regarding trip cancellations, and its drivers may lose some money if they do not abide by these principles.

Moreover, Uber obliges its drivers and riders to comply with the rules of good behaviour, and there are various provisions established to arrange several prospective issues. According to the terms and conditions of the Uber app, the company provides high priority to riders' safety. In cases where a rider experiences an issue with the driver, such as driving carelessly or dangerously, he or she is encouraged to contact the company and report the issue (Uber, n.dj). It has been cited that 'Uber enforces strict safety guidelines to keep' customers' journey 'safe and comfortable. Unprofessional behavior, inappropriate physical contact or verbal aggression from drivers is not tolerated' (Uber, n.dk). For these reasons, the Uber app helps riders recognize the vehicles and the drivers they ride with for every journey. After the trip request is accepted, the app displays the 'driver's name, vehicle make and model, and license plate number'. The rider is encouraged to contact the company if the driver is not who the rider was expecting (Uber, n.dl). On the contrary, drivers must report to the company any material that is left behind by riders (Uber, n.dm). Moreover, in cases where a rider makes a mess in the driver's car that prevents him or her from accepting further rides, Uber might pay a certain amount of money to the driver in order to clean the car. In this regard, it is worth noting that according to the information provided on Uber's website, the driver should inform the company about this issue within three business days along with the photos of the mess, and the company evaluates the situation and contacts the rider if necessary, but if the evidence provided is insufficient' or if the company is 'not able to match the claim with' the rider, it 'may be unable to provide reimbursement' (Uber, n.dn). Hence, it is clear that Uber supervises and manages the behaviour of its drivers.

On the basis of previous examinations, it is significant to mention that the Superior Commission for the Settlement of Labour Disputes issued a significant principle, in judgement No. 1088/2/431 dated 26 October 2010, affirming that because the plaintiff, who had worked as an otolaryngologist and signed a medical cooperation agreement with a hospital, had the freedom to 
manage his work time, the contract between the parties was a cooperation agreement. Then, it did not indicate that the plaintiff was a worker and the defendant was an employer, even if it was agreed that the plaintiff's wage would be a certain percentage of the sale given to him at the end of each month. The forum did not have jurisdiction over the issue and the Saudi Labour Law shall not be applied to the litigation (The Code of the Labour Principles and Judgements, 2010, vol. 1, pp. 280-285). In spite of this ruling, there is a high probability that all the elements, provided in section 1 of article 5 of the Saudi Labour Law and required to govern the employment agreement by the Saudi Labour Law and to consider these drivers as workers, are getting fulfilled for Uber drivers in Saudi Arabia. Also, it seems that there is nothing in Islamic rules to prevent these drivers from being regarded as workers. This is because the services they provide, such as taxi or food delivery services, are allowed in accordance with the rules of Sharia. In addition, the fare and task for the services are figured out and identified for the parties before they both accept the work. On the basis of this outcome, digital platform workers, such Uber drivers, should be regarded as workers in accordance with the Saudi Labour Law and are entitled to be protected by the Law, as long as certain criteria to apply the Law are met. Then, the enterprises providing their services through digital platforms are obliged to grant all the rights enacted in the Law to their digital platform workers. This outcome means that these institutions have many obligations towards these workers. For example, their wages are protected from unlawful deductions and should not be less than the national minimum wage when applied, they get rest breaks, they are paid the end-of-service bonus, and their working time is limited to weekly working hours. Moreover, the employers are obliged to offer a free health insurance to the workers who must also be registered in the Saudi Social Insurance Law. More significantly, the provision of Article 8 of the Saudi Labour Law shall be applied to such work contracts. It articulates that 'any condition that contradicts the provisions of this Law shall be deemed null and void. The same applies to any release or settlement of the worker's rights arising from this Law during the validity of the work contract, unless the same is more beneficial to the worker'. Hence, it appears that persons providing their services via technology platforms, such Uber drivers, in Saudi Arabia fall within the scope of the jurisdiction of the Saudi Labour Law.

On the basis of the conclusion of the previous paragraph, it is important to mention that 'the traditional scheme of subordinate work does not respond adequately to the reality of the new business models that are being developed through digital platforms' (Vizuete, 2019). In this context, the Saudi Ministry of Human Resources and Social Development, which has taken significant steps to develop the labour market in Saudi Arabia, may have a logical solution for digital platform workers. This is because the Minister of Human Resources and Social Development issues Decree No. 142906 dated 07 April 2020 to regulate the principles of flexible working in Saudi Arabia, and the main features of these rules are that they are not mandatory to be applied and employers are free to hire workers in accordance with these rules. Flexible working means the work performed by a part-time worker, who must be a Saudi citizen, on behalf of one or more employers for an hourly wage, provided that the working hours with each employer are less than half of the usual working hours at the firm and not more than 95 hours a month. In addition, when the worker is asked to work at any time, he or she shall have the right to consent or reject the request without taking any legal action against him or her. Also, the worker who shall not be subject to probationary period is not entitled to obtain compensation for various types of paid leave, such as annual and sick, or receive any end-ofservice awards. In addition, he or she must be registered in the Annuities Branch established in the Saudi Social Insurance Law, complying with the standards and norms issued by the General Organization for Social Insurance. Moreover, worker's wages, which shall be an hourly rate, must be paid on a monthly basis or so agreed by the parties involved, and the working hours have to be specified, and could be modified, by the agreement of the parties. Furthermore, the employment contract, which has to be notarized by or registered on the web portal of the Saudi Ministry of Human Resources and Social Development, should be for a definite term and agreed to electronically. Moreover, the Court of Labour Disputes has jurisdiction to rule on the prospective issues between parties. According to the Ministerial Decree, the rules of flexible working would be operational on 04 
July 2020, and the providers of flexible working in Saudi Arabia shall be adopted on the basis of certain standards that are available on the web portal of, and defined by, the Saudi Ministry of Human Resources and Social Development. It has also introduced various rules and regulations to regulate remote working and to organize self-employment in Saudi Arabia. In fact, according to the recent rules provided by the Saudi Ministry of Human Resources and Social Development, it seems that the drivers rendering their services by digital platforms are regarded as freelancers, and there is a special financial support for them in Saudi Arabia if certain requirements are met. Some of these stipulations are that the drivers must be Saudi and do not work in private or public sectors (Selfemployment Platform, n.d).

\section{Conclusion}

This paper has sought to find an appropriate approach for digital platform workers, such Uber drivers, in Saudi Arabia, and the main question is 'Could the Saudi Labour Law regard them as workers?' In this study, it has been revealed that the general rules in Saudi laws must be taken into account by enterprises offering services via digital platforms and the persons employed in these services. It has also examined the requirements that ought to be available in any employment agreement in order for it to be governed by the Saudi Labour Law. Further, this research has investigated the availability of such elements in this sort of business model in Saudi Arabia by examining Uber's website which is one of the oldest and biggest enterprises that employed people through digital platforms in Saudi Arabia. There are significant findings of this research, which are mentioned below, and this paper concludes with recommendations for future studies.

It has been shown clearly that although enterprises providing their services through digital platforms in Saudi Arabia may allow their digital platform workers to work on behalf of other competitors providing the same services or other employers, Saudi law prohibits military officers, public servants and non-Saudi workers in the private sector from working on behalf of other employers or being in self-employment. At the same time, the Saudi Labour Law does not regulate the point of preventing Saudi workers in the private sector from working on behalf of other employers, and therefore, the employment agreement might regulate this subject matter. Moreover, the Regulation for Taxi, Taxi Broker and Taxi Delivery Apps in Saudi Arabia implies that a non-Saudi worker shall not be employed as a driver through digital platforms, and the providers of these services must monitor and supervise their drivers. If they fail to follow the rules of the Regulation, defined punitive measures may be taken against them.

In spite of the fact that this paper examined Uber's website, which is one of the oldest and biggest institutions providing taxi services via technology platforms in Saudi Arabia, to reveal the legal nature of the work relationship between persons and the companies offering their services, and employing them, through digital platforms, the outcomes of this study would be useful for all digital platform workers in Saudi Arabia.

It has not yet found a judgement issued by the competent forums for labour disputes in Saudi Arabia that provide a clear answer to the question of whether or not persons adopting digital platforms to offer their services, such as drivers providing taxi or food delivery services, are considered workers. However, pursuant to Section 1 of Article 5 of the Saudi Labour Law, the Law should be called to govern any work contract if the subject matter of the agreement is to perform a specific work for an employer and for a certain wage, provided that the employer exercises control and supervision over the worker's work. In reality, the most important element in the employment agreement is the governance and management of the employer because there are several legal contracts whose subject is to perform certain works for fixed wages, but the agreement that shall be governed by the labour law is when the employer has control over the worker's performance of employment duties. In this context, it suffices to call the labour law to govern the work relationship between such a taxi driver and the owner of the vehicle he or she is driving if the owner compels the driver to wear a specific dress when he or she drives the taxi or displays a specific behaviour with the 
riders. Also, the labour law should govern the agreement if the vehicle's owner is responsible for repairing the damage of the car in an accident or paying financial compensation to the driver in such circumstances.

Consequently, it can be said that when the previous standards are applied to the work relationship on digital labour platforms, such as Uber app, in Saudi Arabia, there is a high likelihood that this sort of work contract shall be governed by the rules of the Saudi Labour Law, in particular, when this business model does not contain any obvious flaw that makes it forbidden in accordance with Islamic rules. This is because the persons, such taxi drivers, commit themselves to work for wages as a certain percentage of the fare paid by the customers, as mentioned on Uber's website. In fact, Uber, for example, exercises a high degree of supervision and management over its drivers; they cannot join the company unless certain stipulations are met. Also, Uber controls the fare for each trip, and its drivers are not allowed to assess the fare for the trip. In addition, it provides free traffic accident insurance to all Uber drivers, passengers, riders and delivery partners.

On the basis of the previous facts, the digital platform workers, such as Uber drivers, are entitled legally to obtain all mandatory rights enacted in the Saudi Labour Law. For example, their wages should not be less than the national minimum wage when applied, they shall not work more than weekly working hours and they must have paid annual holiday as legislated in the Law. More importantly, they must be enrolled in the Saudi Social Insurance Law, and the end-of-service bonus should be paid to them. On the other side, the Saudi Ministry of Human Resources and Social Development has recently established rules to regulate flexible working, remote working and selfemployment in Saudi Arabia that should provide a useful approach for the parties depending on this kind of business model. In fact, according to the recent provisions provided by the Saudi Ministry of Human Resources and Social Development, it appears that Taxi drivers rendering their services through technology platforms are considered as freelancers, and they are entitled a special financial support in Saudi Arabia if certain stipulations are fulfilled.

As to future studies, there is a huge need to thoroughly explore the possibility of applying, or not, the Saudi Labour Law to govern such cases when the parties involved in digital labour platforms have agreed to refer the prospective disputes to the arbitration. This is because Articles 9 and 12 of the Saudi Arbitration Law provide the provisions that the parties to a contract are allowed to incorporate a clause in the agreement providing for settlement of disputes through arbitration or might agree to do so after the issue arises. In such situations, when the rules of the Saudi Arbitration Law and its implementation regulations are applied, it should consider Article 38 of the Saudi Arbitration Law, which establishes the following:

1. Subject to provisions of Sharia and public policy in the Kingdom, the arbitration tribunal shall, when deciding a dispute, consider the following:

a. Apply to the subject matter of the dispute rules agreed upon by the arbitration parties. If they agree on applying the law of a given country, then the substantive rules of that country shall apply, excluding rules relating to conflict of laws, unless agreed otherwise.

b. If the arbitration parties fail to agree on the statutory rules applicable to the subject matter of the dispute, the arbitration tribunal shall apply the substantive rules of the law it deems most connected to the subject matter of the dispute.

c. When deciding the dispute, the arbitration tribunal shall take into account the terms of the contract subject of the dispute, prevailing customs and practices applicable to the transaction as well as previous dealings between the two parties.

2. If the two parties to arbitration expressly agree to authorize the arbitration tribunal to settle the dispute amicably, it may rule on the dispute in accordance with the rules of equity and justice. 


\section{References}

Abdualredha, A. (1984). Alwajeez in Kuwaiti Labour Law. ( $2^{\text {nd }}$ ed). Kuwait: Al Manhal Library.

Abdulrahman, A. and Rushdy, M. (2009). The Law of Labour and Social Security. Benha: Benha University.

AlAhmed, S. (2015). Alwajeez in the Saudi Labour Law: A Study on the Saudi Labour Law issued by Royal Decree No. M/51 dated 23/o8/1426 (27 September 2005). ( $1^{\text {st }}$ ed). Riyadh: Dar Al Uloom University.

Alawawdah, S. (2010). The Obligations and the Rights of the workers in Sharia: A Comparative Study with the Palestinian Labour Law. Master thesis. Jerusalem: Al-Quds University.

Aldumky, M. (2012). The New Saudi Labour Law in the Balance of the Doctrinal Analysis: A Detailed Description for the Rules of the Saudi Labour Law Issued by Royal Decree No. M/51 dated 23/08/1426 H (27 September 2005) Approval of the Council of Ministers Resolution No. 219 dated 22/08/1426 H (26 September 2005). $\left(3^{\text {rd }}\right.$ ed). Jeddah: Dar Hafiz for Publishing and Distribution.

Allamsawi, A. (2007). The Rights and the Obligations of the Workers and Employers in Arabic Agreements and Laws in All Arab States. ( ${ }^{\text {st }}$ ed). Cairo: The National Centre for Legal Publications.

Al Omran, A. (2014). Ride-Sharing App Uber Launches in Saudi Arabia, in the Wall Street Journal. [Online] Available: https://blogs.wsj.com/middleeast/2014/05/22/ride-sharing-app-uber-launches-in-saudi-arabia (accessed March 26, 2021).

Alothaimeen, M. (2005). Alsharh Almumtea Ala Zaad Almustaqnea. Vol, 10, (1st ed). Dammam: Dar Ibn Aljawzi.

Bani Khalaf, H. (2018). Alwaseet for Explain the Saudi Labour Law in Light of the Principles and Judgment of the Labour Disputes Settlement Body. (1 $\mathrm{1}^{\text {st }}$ ed). Riyadh: International Publishing House.

Chernev, A. (2017). The Business Model: How to Develop New Products, Create Market Value and Make the Competition Irrelevant. Chicago: Cerebellum Press.

Ghawi, A. (2018). 100 Million Trips by Apps for Taxi Services in a Year, in Riyadh Newspaper. [Online] Available: http://www.alriyadh.com/1716825\# (accessed March 25, 2021).

Hadfy, B. (2015). Alwajeez in Explanation of Labour Law: An Individual Labour Relationship. (3 ${ }^{\text {rd }}$ ed). Algiers: Joussour for Publication and Distribution.

Musa, K. (2018). The New on the Explanation of the Labour Law and the Law on Social Insurance in Saudi Arabia in Accordance with the Latest Amendment Issued by Royal Decrees No. M/46 dated 05/06/1436 H (26 March 2015), No. M/45 dated 07/07/1427 H (o2 August 2006), and No. M/33 dated 03/09/1421 H (30 November 200o). ( $2^{\text {nd }}$ ed). Riyadh: University Book House.

Self-employment Platform. (n.d). Common Questions for Directed-Transport Programme. [Online] Available: https://freelance.sa/faq (accessed July 06, 2021).

Uber. (2020). Uber Community Guidelines, MIDDLE EAST AND NORTHERN AFRICA. [Online] Available:https://www.uber.com/legal/ar/document/?name=general-communityguidelines\&country=saudi-arabia\&lang=en (accessed March 21, 2021).

Uber. (2018). Rider Injury Protection. [Online] Available: https://www.uber.com/en-SA/blog/rider-injuryprotection/ (accessed March 26, 2021).

Uber. (n.da). What Is Uber?. [Online] Available: https://help.uber.com/en/partners/article/what-isuber?nodeId=eac2e43e-af 42-4521-ao42-2982c18664af (accessed March 21, 2021).

Uber. (n.db). What is the Uber fee?. [Online] Available: https://help.uber.com/en/driving-anddelivering/article/what-is-the-uber-fee-?nodeId=5704e643-6df8-47ce-bcb2-a3968a445bcc (accessed March 23, 2021).

Uber. (n.dc). I Want to Drive in a New City. [Online] Available: https://help.uber.com/partners/article/i-want-todrive-in-a-new-city?nodeId=7b58do71-3b65-41e3-9do1-1b3b639a9671 (accessed March 29, 2021).

Uber. (n.dd). Paying with Cash. [Online] Available: https://help.uber.com/en/riders/article/paying-with-cash?nodeId=baozbcbo-4bdc-417a-a236-8fe1582adffc (accessed March 21, 2021).

Uber. (n.de). My Direct Deposit Is Late or Missing. [Online] Available: https://help.uber.com/partners/article/mydirect-deposit-is-late-or-missing-?nodeId=38e1f3a9-139a-4cd9-9of3-daaa915871ob (accessed March 25, 2021).

Uber. (n.df). My Fare Was Adjusted. [Online] Available: https://help.uber.com/partners/article/my-fare-wasadjusted-?nodeId=5f9a6dc9-0357-41b7-be1b-912cb883ee46 (accessed March 22, 2021).

Uber. (n.dg). Making Multiple Stops on a Trip. [Online] Available: https://help.uber.com/partners/article/makingmultiple-stops-on-a-trip-?nodeId=a44dba69-1994-4697-8b6b-9be56fc58f3o (accessed March 28, 2021).

Uber. (n.dh). Why Is My High Fare Not Showing Up? [Online] Available: https://help.uber.com/en/partners/article/why-is-my-high-fare-not-showing-up-?nodeId=68a79ofd-of6d-41999753-e4da120122e5 (accessed March 28, 2021). 
Uber. (n.di). Am I Charged for Cancelling an Uber Ride? [Online] Available: https://help.uber.com/riders/article/am-i-charged-for-cancelling-an-uber-ride-?nodeId=5f6415dc-dfdb4d64-927a-66bbo6bc4f82 (accessed March 23, 2021).

Uber. (n.dj). My driver drove dangerously. [Online] Available: https://help.uber.com/riders/article/my-driverdrove-dangerously?nodeId=833301f6-392f-486a-b274-4d 57db2c19aa (accessed March 21, 2021).

Uber. (n.dk). My Driver's Behavior Made Me Feel Unsafe. [Online] Available: https://help.uber.com/en/riders/article/my-drivers-behavior-made-me-feel-unsafe----?nodeld=afeeezc5c152-46dc-bae9-e1oc10902cb1 (accessed March 30, 2021).

Uber. (n.dl). My Driver Didn't Match the Profile in My App. [Online] Available: https://help.uber.com/en/riders/article/my-driver-didnt-match-the-profile-in-my-app-?nodeld=518oc336dod7-4b71-946f-do21bcdf4586 (accessed March 22, 2021).

Uber. (n.dm). I Found an Item. [Online] Available: https://help.uber.com/partners/article/i-found-anitem?nodeId=cdbfefce-bb8a-4ffd-847f-ad8oac4bief6 (accessed March 28, 2021).

Uber. (n.dn). A Rider Made a Mess in My Vehicle. [Online] Available: https://help.uber.com/partners/article/arider-made-a-mess-in-my-vehicle?nodeId=6a6obda7-d8a6-46b7-bd95-2cdf62c7e987 (accessed March 30, 2021).

Vizuete, E. G. (2019). Legal Characterization of the Worker in New Forms of Employment: Reflections on the Subjective Scope of Labour Law. E-Journal of International and Comparative Labour Studies, vol. 8, n. 3, 119.

Zaki, M. (1982).The Employment Agreement in Egyptian Law. ( $2^{\text {nd }}$ ed). Cairo: Public Egyptian Authority for Books. 